\title{
ПРОБЛЕМИ ІНТЕРПРЕТАЦІЇ УКРАЇНСЬКОЇ ЛІТЕРАТУРИ І ФОЛЬКЛОРУ
}

УДК 821.161.2-1-97

Ірина ДАНИЛЕНКО

д. філол. наук, професор,

Чорноморський національний університет імені Петра Могили (м. Миколаїв)

\section{МОЛИТВА ГОСПОДНЯ В ХУДОЖНІЙ РЕЦЕПЦІЇ УКРАЇНСЬКИХ ПОЕТІВ}

У статті проаналізовано головні тенденції процесу творчого сприйняття українськими поетами ранніх періодів розвитку національної літератури тексту найбільш авторитетної християнської молитви - «Отче наш». Виходячи 3 переконання, що молитва $є$ дзеркалом духовної зрілості людини, дослідниця пояснює взаємодію етичних домінант християнської доктрини 3 авторською аксіологією, а також провідними етичними, філософськими і естетичними тенденціями епохи.

Ключові слова: українські поети, Молитва Господня («Отче наш»), молитва канонічна/ поетична, сакральний оригінал, поетична інновація.

Як зазначають отці Церкви, молитва - це відповідальна праця і велике мистецтво, якого треба навчатися, бо інакше розмова 3 Богом тільки «посилить внутрішній душевний хаос людини» [10, с. 157]. Недарма апостол Павло говорить: «Страшна річ - упасти в руки Бога Живого!» (Свр. 10:31). Християнин має спочатку засвоїти цінний соборний досвід молитви і лише тоді приступати до Бога зі своїми особистісними інтенціями, оформленими суто індивідуальними вербальними засобами. Адже, на відміну від соборної молитви, в індивідуальному молитовному зверненні набагато яскравіше проявляється власна воля молільника, яка в разі розходження з Божою волею може зашкодити людині. Молитви ж угодників Божих апріорі «поставлені правильно»: адже вони онтологічні (себто є плодом дії Святого Духа) та синергійні (у літургійній молитві віра, богослов’я і життя сходяться в одне); 
тому завдяки своїй універсальності можуть діяти на людину непомітно, i навіть супроти їі волі [10, с. 157-158].

Тож молитва потребує навчання, а найкращі вчителі на цьому шляху це молитви, що освячені авторитетом Святого Письма та святих. Християнська Церква, засвоївши досвід старозавітної молитви, увібравши в себе деякі молитви з Свангелія та Апостольських Послань, а також оригінальні молитви, створені св. отцями Церкви ${ }^{1}$, сформувала стійкий, хоча й досить гнучкий, динамічний змістовий канон, який вона дбайливо підтримує впродовж століть. Так, приміром, ранішнє та вечірнє домашні правила не змінюються протягом багатьох століть i утворюють те ядро, навколо якого можливе народження нових молитов. Такі молитви інколи вміщують у додатку до Молитовника, проте увійти до молитовного правила жодній новій молитві з часів Симеона Нового Богослова (поч. XI ст.) не вдалося.

Найавторитетнішою з-поміж християнських канонічних молитов $\epsilon$ Молитва Господня (або «Отче наш»), оскільки, по-перше, за Євангелієм, іiі дав сам Господь Ісус Христос у відповідь на прохання апостолів навчити їх молитись (Мт., 6:9-13). По-друге, вона, за словами св. Симеона, архієп. Солунського, стисло охоплює всю Свангельську істину [4, с. 522]. По-третє, вона дає вичерпне розуміння про форму й зміст християнської молитви, оскільки містить усі можливі в ній структурні складові, зокрема: прикликання Творця, адресоване Йому славослів'я і сім прохань, зосереджених переважно на духовному вдосконаленні людини. Навіть прохання про хліб на кожний день отці Церкви, зокрема препод. Кассіан Римлянин, трактує як щоденну потребу людини зміцнювати своє серце духовним знанням у сьогоденному (тобто земному) житті [4, с. 410-411]. А в цілому з християнської точки зору прохання в молитві - проти гордої плоті

\footnotetext{
${ }^{1}$ Переважну більшість молитов укладено в період Вселенських Соборів такими великими отцями Церкви, як св. Іоанн Златоуст, св. Василь Великий, св. Григорій Богослов, преп. Антоній Великий, преп. Макарій Великий, преп. Сфрем Сирієць (Сирін), преп. Іоанн Дамаскін, преп. Симеон Новий Богослов та інші.
} 
нашої, яка все приписує собі; подяка - проти нечутливості плоті нашої до незліченних благодіянь Божих, славослів'я - проти плотської людини, що шукає слави лише для себе [7, с. 3].

Зважаючи на те, що молитва є дзеркалом духовної зрілості людини [8, с. 120], а Молитва Господня - взірцем християнського звернення до Творця, яке стисло репрезентує християнське вчення загалом, аналіз поетичних модифікацій «Отченашу», вважаємо, мусить із найбільшою очевидністю оприявнити особливості засвоєння вітчизняними поетами i репрезентативного молитовного канону в контексті провідних етикофілософських та естетичних тенденцій доби загалом, i відповідні індивідуально-авторські морально-ціннісні й світоглядні домінанти, зокрема.

Українська традиція літературної інтерпретації канонічних молитов сягає часів другого південнослов’янського впливу. При цьому саме молитва «Отче наш», за версією К.Тарановського, вже в церковнослов’янському біблійному перекладі була відтворена не прозою, а руським молитовним віршем [14]. Згідно з цією концепцією «Отче наш» розпадається на два п’ятивірші, де 5-й і 10-й рядки закінчуються каденцією (позбавленням ритмічної напруги), а решта вісім рядків - позначені специфічним у молитвословному вірші ритмічним сигналом, у функції якого виступають дві граматичні форми - кличний відмінок і наказовий спосіб та синтаксична інверсія:

Отче наш, иже еси на небесах,

Да святится имя твое,

Да приидет царствие твое, Да будет воля твоя,

Яко на небеси и на земли.

Хлеб наш насущний даждь нам днесь,

И остави нам долги наша,

Яко же и мы оставляем должником нашим,

И не введи нас во искушение,

Но избави нас от лукавого [14, с. 257].

Власне художнє переосмислення та актуалізація базових концептів Молитви Господньої в українському дискурсі починається лише 3 XVII ст. 
Так, першою віршованою інновацією «Отченашу» на східнослов’янському грунті стала, вочевидь, лірико-філософська поема українського богослова й письменника Кирила Транквіліона-Ставровецького «Похвала пренасвһтейшей персонһ Отцовской» (із збірки «Перло многоцһнное»), поява якої припадає на середину XVII ст. - знаменний в історії української літератури період, позначений не лише пануванням «впорядкованого», себто силабічного вірша, а й справжнім розквітом жанру віршованої молитви. Відтоді традиція модифікації Молитви Господньої в українській поезії триває й до сьогодні. Після К. Транквіліона-Ставровецького до художньої інтерпретації «Отченашу» зверталися такі поети, як: Юрій Федькович, Михайло Старицький, Спиридон Черкасенко, Павло Штокалко, Осип Маковей, Микола Хвильовий, Євген Плужник, Марійка Підгірянка, Юрій Шкрумеляк, Володимир Янів, Дмитро Павличко, Семен Бабій, Антоніна Листопад, Василь Кредо та ін.

Так, «Похвала пренасвһтейшей персонһ Отцовской» Кирила Транквіліона-Ставровецького, яка $\epsilon$ складовою частиною більш великої панегіричної композиції - книги «Перло многоцһнноє», відзеркалює загальну тенденцію вітчизняних поетів XVII століття тлумачення Святого Письма у річищі поєднання дидактичної місії з грою слів і семантичних відтінків, себто герменевтики 3 риторикою [9, с. 100]. Жанр «похвали», до якого звернувся Кирило з метою художньої інтерпретації «Отченашу», до того жє основним жанром риторики 3 притаманними їй апріорним подивом перед кожним предметом і ключовою ідеєю ясності, себто з готовністю водночас і до славослів'я, і до пояснювання. Вірші тут слугували художнім засобом привертання уваги до християнського вчення, аби «чловһк охотнһшій был до читання речій боязких и таһмниць збавеных» $[15$, с. 231]

Відтворюючи загальну композицію Молитви Господньої, яку складають звернення зі славослів'ям та сім прохань, Кирило будує свій твір з вісьмох відповідних частин («статей») за принципом ампліфікації, себто семантичного розширення кожної інтенції релігійно-культового тексту. 
Оскільки молитва становить собою одну 3 основних форм релігійної експресії, усі «статті» Кирилової «Похвали» орієнтовані і на те, щоб оживити зміст Молитви Господньої, і на те, щоб прославити Боже ім'я та Божий Промисел. Визначальною рисою всіх його «статей»-молитов $є$ розгорнута риторична частина, де повторюються, варіюються та інтерпретуються ключові поняття окремої молитовної інтенції «Отченашу». Уся поема Кирила пронизана почуттям безмежної віри й любові до Бога, подивом перед Його неосяжною величчю та безмірною надією на Боже Спасіння. Втім, саме цей магістральний лірико-філософський настрій зумовлює появу інтенцій іншого плану - ненависті молільника до «гнівливого і злосливого» диявола (який «Бһсится и пһнится блудними нечистотами / А от убивства играє кривавыми волнами» $[15$, с. 242$])$, та величезного страху суб'єкта молитви потрапити в полон до лукавого. Негації молільника стосовно головного Божого антагоніста, що промовисто відтворені у двох останніх поезіях циклу, стають експресивно-емоційною основою для його скарг на «вразів» [15, с. 241], «псів пекельних» $[15$, с. 242] та відповідно для слізних благань до Бога послати пресвітлих ангелів «на ратунок душһ», аби оборонити ії від «лукавого врага» [15, с. 242-243] на віки вічні.

У поезії Нового часу прагнення митців за допомогою молитовної форми вдатися до морального самозаглиблення, відтворити власні думки і переживання щодо найважливіших проблем історії та сучасності позначилися й на характері віршових обробок Молитви Господньої. Почасти досить розгорнуті поезії-моління старожитнього періоду поступаються місцем набагато лаконічнішим віршованим зверненням до вищих сил. Переспіви, в яких автори майже буквально наслідують «дух і букву» першоджерела, складають помітну меншість (див.: «Молитва Господня (“Отче наш”)» із «Віршованого молитвослова» Василя Кредо). Переважна більшість українських інновацій Молитви репрезентують подальший розвиток започаткованої у вітчизняній поезії Шевченком романтичної 
традиції поєднання містичного почуття 3 вірою в можливість соціального раю.

Так, зокрема, якщо Кирило Транквіліон-Ставровецький у своєму парафразі Молитви Господньої говорить про Царствіє Небесне як про «сокровенноє», «не мира сего лестивого» [15, с. 237], підкреслюючи його трансцендентну природу, то переважна більшість українських поетів (Павло Штокалко, Юрій Шкрумеляк, Степан Бабій, Марійка Підгірянка, Антоніна Листопад та ін.) прирівнюють Царство Небесне до земного благоденствія. Див., приміром:

$<. . .>$ I царство пресвяте Твоє

Най між людьми настане,

Най щезне з світу всяке зло,

Най зникне все погане [16, с. 134].

(П. Штокалко. «Отче наш», б/д) тощо.

До того ж, цілком знаходячись у річищі цієї основної тенденції, більшість поетів (Ю. Шкрумеляк, С. Бабій, Марійка Підгірянка, Антоніна Листопад та ін.) перетворюють «Отче наш» на певний варіант молитви за Україну - надзвичайно популярний в українському поетичному дискурсі. Див., наприклад:

Отче наш, що в небесі єсі,

Україну нам спаси.

Най святиться Твоє ім'я

Й українське знам'я.

Най Твоє царство нам прийде,

Зірницею зійде.

Най воля Твоя буде нам,

України синам... [16, с. 139].

(М. Підгірянка. «Отче наш», б/д).

Наскрізним при цьому стає мотив страждання українського народу, який потребує Божої милості за минулі мучення, порятунку, а також міцного й вірного захисту від можливих негараздів у майбутньому:

$<. .>$ Ти з висот небесних бачиш наші труди,

Знаєш біль народу, чуєш плач дітей,

О, най Твоє Царство, Господи пребуде,-

Царство мира й ласки, Господи святий! [16, с. 161]

(Ю. Шкрумеляк. «Отче наш!», б/д). 
$<$... Р Молимося за безвинно убієнних і мучених,

Страждальців за волю і гідність людську,

За великі жертви народні

На дорогах війни і в години великого смутку,

За дітей Твоїх українських [16, с. 319].

(О. Бабій. «Молитва», 1991)

Мотив святого мучеництва українського народу в підтексті присутній і в поезії Антоніни Листопад «Вкраїнський Отченаш», в інтерпретації якої заключне мале славослів'я «В ім’я Отця, Сина і Святого Духа. Амінь» (що означає, по суті, «да буде так в ім'я Триєдиного Бога»), модифікується завдяки новим ідеальним реципієнтам - «Матері», «вкраїнським дочкам», «Вкраїні». Поставлені в один ряд 3 «Вітцем» $\mathrm{i}$ «Сином» та «Великим Духом Святим», вони переорієнтовують усталену рецепцію читача, який починає сприймати традиційного ідеального адресата Молитви Господньої у розширеному діапазоні: і як велику українську родину (де є місце і матері, i синам, i дочкам), i як єдине Лице Боже (Отець, Син і Святий Дух) та Богоматір:

Отче наш... Що єси!

Хай святиться ім'я Твоє

На українській землі.

Хай буде воля Твоя в усій Україні.

Спаси і помилуй

Вкраїнські душі невинні.

I нас, винуватих, спаси.

Во ім'я Вітця, і Матері, й Сина.

I дочок вкраїнських.

Во ім'я Вкраїни.

Во ім'я Великого Духа Святого

Направ на єдину священну дорогу

I нині, і присно, навіки віків.

Амінь... [16, с. 342].

Промовистим винятком із цієї основної тенденції громадянськопатріотичного осмислення «Отченашу» в новочасній поезії $\epsilon$, наприклад, вставна молитва Осипа Маковея «Наш Отче, що на небесах єси...» із поеми «Терновий вінок», де саме прохання про Царствіє Небесне стає центральним мотивом твору, викликаючи відповідні ліричні роздуми, згідно з якими «царство боже, повне див / немов країну чарівну, прекрасну» [16, с. 104] поет знаходить в чистій душі «пророка» і «страждальця», вбитого «темнотою 
людською», вочевидь натякаючи на постать розп’ятого Христа. Звідси i мотив каяття, і прохання про духовну допомогу:

Бо ми слабі, бо ми слабі, о Боже! Наш дух, як гадина, не має крил. Твого царства віднайти не може, прощати ворогам - не має сил.

Наш отче, що на небесах єси, нехай прийде на землю власть твоя! Ти людям суд свій праведний даси, і буде нам святе твоє ім'я! [16, с. 104]

В українській літературі пореволюційних часів через радикальну зміну соціально-політичного, економічного життя, а головне - ціннісних орієнтирів спостерігаємо і більш кардинальне переосмислення Молитви Господньої. Так, приміром, у вірші-стилізації «Отче наш» Спиридона Черкасенка з усіх прохань Молитви поет обирає, вірогідно, найактуальніше на той час - про хліб насущний, трактуючи його в буквальному, суто прагматичному ключі:

Всесильний Отче! Хліб насущний

Подай ти нам хоч днесь...

I ніч, і день увесь

Молюсь тобі, о непорушний,

Холодний!

Дай хліба нам,

Твоїм рабам [16, с. 119].

Суттєва трансформація змісту канонічної молитви супроводжується тут запереченням жанрового канону християнської молитви загалом. Націленість «молільника» на отримання бажаного та очевидна відсутність у нього віри в Боже Провидіння перетворює молитовне звернення до Бога на абсурдний по своїй суті ультиматум з елементами інвективи:

Не дай же мукам вщерть

Залить серця, злобою п’яні,

І в бурі розпачу й зневір'я

Посипать попелом чоло, Подрать одежу на ганчір'я

І за терпіння, за все зло,

Наш Отче пребайдужний,

Тебе навіки проклясти, 
О осоружний!

То дай же хліба нам

I, мов голодним псам,

Здихать не попусти!.. [16, с. 119].

Загалом модифікація «молитви молитов» у вірші С. Черкасенка відбувається через пародіювання змісту сакрального тексту: величний, благоговійний тон Молитви Господньої сповнюється у цій інновації сатирично-викривальним пафосом, спрямованим безпосередньо на ідеального реципієнта, тобто Бога.

Ще одна тенденція в поетичному осмисленні молитви «Отче наш» у Новий час - переосмислення образу ідеального адресата згідно 3 «прогресивними» поглядами синів залізного віку на світобудову та його головну рушійну силу. Так, у Миколи Хвильового в поемі «В електричний вік» (фрагмент, що починається з рядка «Отче наш - електричної системи віку!..») місце Бога посідає технічний прогрес, в якому ліричний герой повністю розчиняється, охоче перетворившись на безлику частку великого механізму. Звідси й нова, в дусі залізного століття, антропоцентична «триєдність», що протиставлена «застарілим» уявленням:

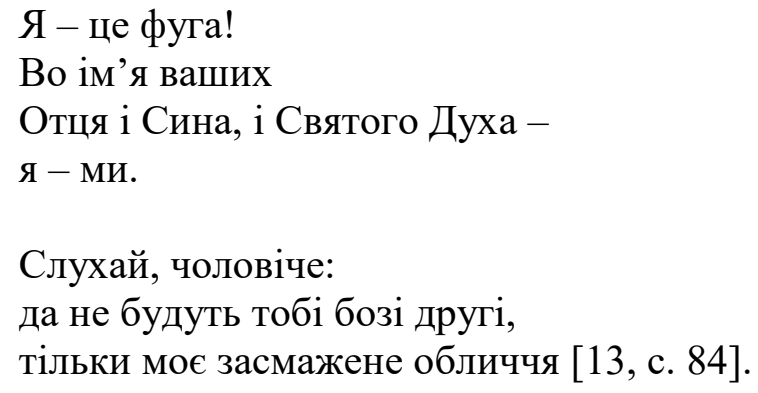

Та ж сама ідея антропософського гуманізму - поклоніння ідеалу самоцінної людини, яка покладається лише на свою волю, міць та вірить лише у свій дух і заповіти свого серця, - лежить і в основі ліричної ситуації вірша у прозі Олеся Бабія «Моя молитва» (1922), що становить собою стилізацію Молитви Господньої:

«<..>I нехай не шукаю чужих богів, не поклоняюся золотим тельцям, а приношу жертву одинокому Богові, що зветься Людина. 
I не хочу знати іншого цілопаління, крім жертви труду та іншої молитви, крім колінопреклоніння Красі й іншого гімну, крім псалма Любові. $<\ldots>$

Да будет воля моя, да будет.

Моя воля і більше нічия!

зневіри.

І да ізбавлю себе сам - не од лукавого, а од знесилля, втоми й

Амінь!» [16, с. 165]

А в поемі Свгена Плужника «Галілей» (1925-1926) ліричний герой уподібнює постаті Бога категорію часу, притім сучасного суб’єктові:

- Нехай буде воля твоя,

Часе мій,

На землі натомленій цій! [12, с. 168-169]

Ще одну тенденцію оприявнює Дмитро Павличко, який у своїй «Молитві» («Отче наш, Тарасе всемогущий...») (1965) замість Творця репрезентує обожнений образ видатної постаті національної історії - Тараса Шевченка (пор. 3 його віршем «Тарасе! Правдо вогнелика!..», 1964). Очевидно, вписуючи постать великого українського поета як ідеального реципієнта до структури стилізації найавторитетнішої християнської молитви, поет прагнув підкреслити надзвичайне, i навіть трансцендентне значення Шевченка як творця української нації:

Отче наш, Тарасе всемогущий,

Що створив нас генієм своїм,

На моїй землі, як правда, сущий,

Б’ющий у неправду, наче грім.

Ти, як небо, став широкоплечо

Над літами, що упали в грузь;

Віку двадцять першого предтечо,

Я до тебе одного молюсь [15, с. 229].

Услід за зміною ідеального адресата - містичного Творця на земного Тараса - в інновації Д. Павличка природно змінюється, порівняно 3 першоджерелом, і характер прохань, які під пером поета перетворюються на численні моління революційного та суспільно-морального змісту:

Язики отруйні й брехливі

Вогняним мечем пообтинай

Проколи серця товсті й ліниві

I гноївки випусти в Дунай.

Всіх вельмож - рабів німих і подлих -

Скинь в геєну, а слова хули - 
Потурнацький, безголовий мотлох -

На вогнях оновлення спали... і т.д. [15, с. 263].

Відповідно до цього Д. Павличком переосмислюється і адресоване Богу славослів'я. Беручи за основу церковнослов'янський текст Молитви Господньої («<..> Да святится имя Твое, да будет Царствие Твое, да будет воля Твоя, яко на небеси и на земли <...>»), поет акцентує лише мотив слова, який виникає наприкінці твору і переосмислюється не в духовно-містичних категоріях, а в національно-культурних:

\author{
Да святиться слова блискавиця, \\ Що несе у вічну далечінь \\ Нашу думу й пісню. Да святиться \\ Між народами твоє ім'я. Амінь [15, с. 264].
}

Дуже цікаво, що міфологічний підхід до зображення персонажів національної історії та оцінки їхньої діяльності, що репрезентовано у наведеному вірші Д. Павличка, був дуже характерним, власне, i для ідеального адресата його «Молитви» - Т.Г. Шевченка, який осмислював відповідні постаті в дусі своєї історіософської концепції (докладно про це див.: [1, с. 66-67]). Але початок традиції обожнення саме постаті Шевченка репрезентовано творчістю П. Куліша, який у ряді творів змальовує Тараса як пророка чи навіть Месію. Адже Шевченко знаменував собою якісно нове явище в українському культурному поступі. Як слушно зауважує М. Грушевський, Куліш «віддав поклін Шевченкові як великому світочеві українського відродження, прирівнявши його появу з приходом Христа» $[13$, с. 37]. Зважаючи на це, вірш «Молитва» Д. Павличка можна кваліфікувати як один 3 найпоказовіших виявів «діалектики процесу міфологізаціїдеміфологізації» (Ю. Барабаш), а радше - процесу сакралізації секулярного і десакралізації містичного, що загалом стає надзвичайно характерним для української поезії Нового часу.

Процес трансформації ідеального адресата Молитви Господньої наочно підтверджує й думку російського філософа I. Ільїна, який твердить, що людина завжди мусить у щось вірити, але при цьому звертає увагу на 
суттєвий семантичний відтінок між поняттями «вірити» i «вірувати». Той, хто не вірує в Бога, чи принаймні в божественне начало, будує свою власну віру, але не має єдиного загального для них усіх духовного центра, на відміну від людей «віруючих» [5, с. 97]. Звідси, вважаємо, потенційна можливість безмежної кількості різноманітних «ідеальних» адресатів у тих літературних молитвах, що наслідують лише зовнішні, композиційно-стильові ознаки релігійно-культового звернення до вищих сил, суттєво модифікуючи його змістовий план.

Наприкінці 30-х - початку 40-х років XX ст. у творчості діаспорного поета Володимира Яніва актуалізується й барокова, започаткована К. Транквіліоном-Ставровецьким традиція розгорнутої («ампліфікаційної») інтерпретації Молитви Господньої. Наслідуючи загальний принцип побудови твору, який складається 3 семи окремих частин-поезій (усі написані 5стопним ямбом), поет, однак, репрезентує зміст, що віддзеркалює новітні тенденції в переспіві сакрального тексту. У В. Яніва багатоскладова структура молитовної ситуації «Отченашу» стала певною матрицею для передачі складних лірико-драматичних почуттів, замість риторики, що посідала головне місце в Кирила. Також на відміну від Кирила, який звертався до Творця у світлій радості подиву перед неосяжною мудрістю Божого Промислу, В. Янів прикликає ім'я Бога «з палаючих глибин нестримним криком, / У розпачи розчарувань - омани», слушно визначаючи свій переспів «Отченашу» як «молитву скриту» «пристрасних бажань» [17, с. 373]. Але з огляду на те, що природа цих бажань поета $є$ духовною, вражаюча щирість та емоційність його суб'єкта-молільника не знищує закладений від начала сенс Молитви Господньої, а по-новому його вияскравлює, актуалізуючи в контексті бурхливої і навіть трагічної сучасності.

Так, у першій поезії, де переспівуються звернення і славослів'я Молитви Господньої («Отче нам, іже єси на небесах, Да святится імя Твоє!») ліричний герой В. Яніва, як свого часу i молільник К. ТранквіліонаСтавровецького, славить Творця, надаючи Йому різні епітети та розгорнуті 
характеристики, що віддзеркалюють глибоке розуміння поетом сутності адресата звернення: «благий Владико», «могутній Пане», «Царю облаків, блакиті / I часу необнятого й простору, / Мільярдів зір, вогненних сонць, всесвіту, / Святої думки поступу і твору» [17, с. 373].

У другій поезії, яка інтерпретує інтенцію «Да прийде изарствіє Твоє», поет із притаманною йому пристрасністю почуттів та поетичною витонченістю вибудовує прохання про Боже Царствіє. Дорівнюючи його Божому «живому, безсмертному слову», яке має вдосконалити людину, врятувавши від загибелі «не лиш вибрані ... народи», молільник звертається до Господа з проханням просвітити духовні очі Його творінь:

Зійди, замешкай в совісті людини,

Вселися в серце кожної істоти:

Хай прийде царство мужності й чесноти -

Вселенна радість доброї новини [17, с. 373].

У третій поезії («Да буде воля Твоя») лірико-драматичне начало значно посилюється, оскільки прохання до Бога стосовно духовної допомоги супроводжується вербалізацією звичайних для людини коливань між сваволею, яка тягне до спокою і земного щастя, та необхідністю з подякою приймати всі випробування, що надсилає Господь. Але, попри всі сумніви, які викликала тривожна пам'ять про тяготи особистого життя, в молільника В. Яніва все ж перемагає віра в Боже Провидіння:

Хоч часом в немочі прошу розради, Не слухай, Господи, прохань знемоги:

Я смерті жах пізнав і друзів зраду

У сірий день страждання і тривоги...

... I спопеліла вже душа у болі:

Я бачив біль, в якім затьмаривсь розум, Розпуки срібні, найсвятіші сльози...

Проте, лиш по Твоїй хай буде волі.

Лиш віра й честь ще не дали упасти!

Прости: вже досить жертв, невдач, отрути.

... Дай радісну, малу хвилину щастя! -

...Прости!...Дозволь на мить одну забути!

Hi! Нi! Зболелого не слухай крику!

Дозволь і силу дай ще раз на жертву!

Бо Ти велів за правду вміти вмерти -

І волі я Твоїй корюсь, Владико! [17, с. 374] 
У четвертій поезії, що присвячена інтерпретації інтенції «хліб наш насущңний даждь нам днесь», автор репрезентує подвійне розуміння цього молитовного вислову: і як прохання про найнеобхідніше для підтримки життя людини - хліб і працю («...Насущний, чорний хліб нам дай щоденно, / Добутий працею в кривавім поті» [17, с. 374]), і як «світло Слова», без якого також неможливо жити. Це дозволило авторові і оприявнити його ставлення до праці («I працю завжди дай мені - роботу, / Щоб жити я не мусив у безділлі...[17, с. 375]»), ідеальне бачення творчості, що має бути «віддихом, не трудом», і висловити своє розуміння поняття «духовна їжа», під яким тут мається на увазі сила духу, віра, любов, добрі вчинки, «світла науки».

П’ята поезія твору, основана на тлумаченні прохання «і оставі нам долги наша, якоже $і$ ми оставляєм должником нашим», збагачується соціальним мотивом, зокрема, темою України. Інспіроване молитовною інтенцією першоджерела каяття молільника, тут раптом перетворюється на сповідь, сповнену «сумніву й одчаю»: ліричний суб'єкт В. Яніва щиро визнає свою неспроможність пробачити національним ворогам «страсті і біль народу»:

За храм збезчещений, собор в руїні,

За кров братів, мордованих в підвалах,

За смерти жах і голод в Україні,

За тих святих, що на хрестах вмирали,

Щоб діти вольними жили у славі,

За підступ, поєне в отруті лезо,

Сибір, Соловки, Казахстан, Березу...[ 17, с. 375].

Ба навіть, попри християнські заповіді, суб’єкт-молільник зізнається у відвертому бажанні покарання цих ворогів:

Або нехай покарані упадуть,

Подолані мечами ляжуть в порох,

Хай просять милостині і пощади!

Хай кається й покутує наш ворог! [17, с. 375]

Але, усвідомлюючи несумісність подібних висловів у зверненнях до Бога, який є любов, ліричний герой В. Яніва знаходить для себе компромісне рішення, формулюючи його спочатку у вислові «Прости їм, Боже! Я не маю права!» [17, с. 375], а наприкінці вірша у рядках: 
То як в боях кривавих - нашим трудом

Підступне плем'я впаде та лукаве

Й на згарищах збудуємо державу,

Прощу їм, хоч ніколи не забуду [17, с. 375-376].

Як відомо, зміст Молитви Господньої обов'язково змушує реципієнта співвіднести себе не лише 3 Богом та Його святістю, а й 3 Божим антагоністом та його спокусами. 3 цієї точки зору цікаво було придивитися, які, можливо, «непрописні» духовні цінності відстоюватиме В. Янів у своїй розгорнутій інтерпретації висловів «і не веди нас во іскушеніє» (шоста поезія), «но ізбаві нас от лукавого» (сьома поезія). Виявилося, що поряд 3 гріхами гордості й марнославства, помсти й заздрості, які його ліричний герой бажав би відвернути від своєї душі, поряд з прагненням міцної віри, яка б захистила праведних від лукавого, по-справжньому животрепетною для В. Яніва стає парадигма поета-пророка і палкого патріота, що іï митець ставить вище навіть за кохання. Так, у шостій поезії-молитві мотив поетапророка становить семантико-композиційний центр, підкреслений до того ж позалексичним засобом виразності (enjambement):

Не кинь в обійми кволої любові, Щоб заглушив я в собі творчий голос //

Твоєї волі і Твоєї мови

І щоб без діл мені посивів волос,

Щоб я ходив в м'яких шовкових путах

І втратив над самим собою владу...[17, с. 376].

У сьомій поезії поет, благаючи Бога про спасіння від лукавого, чисті серця, чисті вуста та освячені Богом шляхи, переводить свій варіант «Отченашу» в український вимір:

Бо як лукавим, злим, безчесним бути //

Між лицарством одважним до загину,

Над Доном, над святим Дніпром чи Прутом,

Між квітами - під небом України? [17, с. 376]

Завершує поему Яніва своєрідний гімн квітучій українській землі чудовому Божому витвору, якому, за поетом, не можна не помолитись, як і не можна його скривдити власною гріховністю:

Бо як лукавим бути тут, у світі, 
Як зелені лісів - Твоїй природі

І синяві шляхів не помолитись

У іскрах сонця й самоцвітах льоду!.. [17, с. 377]

Назагал цей парафраз Молитви Господньої - вагомий внесок В. Яніва у розвиток головної, суто української традиції особистісно-національного та злободенно-політичного прочитання сакрального тексту, але зі збереженням усіх головних морально-духовних концептів першоджерела.

Отож, порівняльний аналіз українських інновацій Молитви Господньої дає змогу стверджувати, що українські поети старожитніх часів прагнули, відтворити та естетизувати всі морально-духовні домінанти Молитви Господньої, очевидно, з просвітницькою метою. Переспіви, наслідування й стилізації «Отченашу» Новітнього часу віддзеркалюють прагнення поетів осмислити свою аксіологію, історико-соціальні, політичні, ідеологічні проблеми часу через глибоко емоційне переосмислення основних концептів зразкового християнського звернення до Бога. Найпопулярніший варіант «Отченашу» в українських поетів XIX-XX століть - переосмислення цього сакрального тексту в дусі молитви за Україну, де наскрізним стає мотив страждання українського народу, що потребує Божої милості та порятунку, i де Царство Небесне прирівнюється життю суспільства в мирі та злагоді. При цьому текст віршової української обробки Молитви Господньої за змістом може суттєво відрізнятися від першоджерела, бо українська поезія наслідує і романтично-бунтарський дух Шевченкової музи, і західну (починаючи 3 часів Реформації) традицію більш вільної інтерпретації змісту релігійнокультових текстів, з опорою на сучасні тенденції в розвитку мови і вірша.

\section{ЛІТЕРАТУРА}

1. Барабаш Ю. Тарас Шевченко: імператив України : Історіо- й націософська парадигма / Юрій Барабаш. - К., 2004. - 181 с.

2. Грушевський М. В тридцяті роковини Куліша : Соціяльно-традиційні підоснови Кулішевої творчості / Михайло Грушевський // Україна. - 1927. - Кн. 1-2. - С. 10-38.

3. Даниленко I.I. Модифікація жанрового канону молитви в поезії нового часу (на матеріалі «Псалмів Давидових» Т.Г. Шевченка) / I.I. Даниленко // Мова і культура : (наук. щоріч. журн.). - К., 2004. - Вип. 7. - С. 18-24. 
4. Добротолюбие в русском переводе : в 5 т. / [пер. с греч. святителя Феофана, Затворника Вышенского]. 1883-1900. Т. 5. - Изд. 2-е, доп. - М., 1888. - (Репринт: СвятоТроицкая Сергиева Лавра, 1992). - 632 с.

5. Ильин И.А. Религиозный смысл философии / Иван Ильин. - М., 2003. - 694 с.

6. Иоанн Кассиан Римлянин. Писания / [Преподобный] Іоанн Кассиан Римлянин. Мн., 2000. - 800c.

7. Иоанн Кронштадтский, св. прав. В мире молитвы / Святой праведный Иоанн Кронштадтский. - СПб., 1991. - 117 с.

8. Иоанн Лествичник, св. Слово о молитве с пояснениями ононого / Святой Иоанн Лествичний // Отцы церкви о молитве и трезвении. - М., 2001. - С. 119-155.

9. Криса Б. Пересотворення світу : Українська поезія XVII-XVIII століть / Богдана Криса. - Львів , 1997. - 219 с.

10. Лєпахін B. Ікона та іконічність / Валерій Лєпахін. - Львів, 2001. - 288 с.

11. Павличко Д. Твори : в 3 т. / Дмитро Павличко. - К., 1989. - Т.1 : Поезії. - 501 с.

12. Плужник $Є$. Поезії / Євген Плужник. - К., 1988. - 415 с.

13. Святі почуття, закладені в молитву : антологія української літературної молитви / [упоряд., автор вступ. ст. і приміток В.І. Антофійчук]. - Бухарест, 2004. - 399 с.

14. Тарановский $K$. Формы общеславянского и церковнославянского стиха в древнерусской литературе XI-XIII вв. // О поэзии и поэтике / Кирилл Тарановский - М. , 2000.- C. 257-273.

15. Українська поезія : Кінець XVI - початок XVII ст. / упорядники В. П. Колосова, В.І. Крекотень. - К., 1978. - 430 с.

16. Хвильовий М. Твори : в 2 т. - К., 1990. - Т.1. Поезія. Оповідання. Новели. Повісті. -650 с.

17. Хрестоматія української релігійної літератури: [у 2 т.]. Т. 2. Кн. 1. - Мюнхен ; Лондон, 1988. - 552 с.

\section{REFERENCES}

1. Barabash Yu. Taras Shevchenko: imperatyv Ukrayiny : Istorio- y natsiosofs'ka paradyhma [Taras Shevchenko: the Ukrainian imperative: historical and natiosophical paradigm], Kyiv, 2004, 181 p [In Ukrainian].

2. Hrushevs'kyy M. V trydtsyati rokovyny Kulisha : Sotsiyal'no-tradytsiyni pidosnovy Kulishevoyi tvorchosti [In thirtieth anniversary of Kulish: social and traditional bases of Kulish's art creativity], Ukrayina, 1927, Vol. 1-2, pp. 10-38 [In Ukrainian].

3. Danylenko I.I. Modyfikatsiya zhanrovoho kanonu molytvy v poeziyi novoho chasu (na materiali «Psalmiv Davydovykh» T.H. Shevchenka) [Modification of genre tradition of prayer in the new time poetry (in "David's Psalms"], Mova i kul'tura, Kyiv, 2004, Vol. 7, pp. 18-24 [In Ukrainian].

4. Dobrotolyubye v russkom perevode: v $5 \mathrm{t}$. [Love for kindness in the Russian translates: in 5 volumes], Vol. 5, Moskva, 1888, 632 p [In Russian].

5. Il'yin I. A. Religioznyy smysl filosofii [Religious meaning of philosophy], Moskva, 2003, 694 p [In Russian].

6. Ioann Kassian Rimlyanin. Pisaniya [Works], Minsk, 2000, 800 p [In Russian].

7. Ioann Kronshtadtskiy. V mire molitvy [In the world of prayer], Sankt-Peterburg, 1991, 117 p [In Russian].

8. Ioann Lestvichnik. Slovo o molitve s poyasneniyami onogo [A word about prayer with its explanation], Ottsy tserkvi o molitve $i$ trezvenii [Fathers of Church about prayer and soberness], Moskva, 2001, pp. 119-155 [In Russian].

9. Krysa B. Peresotvorennya svitu : Ukrayins'ka poeziya XVII-XVIII stolit' [Recreation of world: Ukrainian poetry of XVII-XVIII centuries], L'viv , 1997, 219 p [In Ukrainian].

10. Lyepakhin $V$. Ikona ta ikonichnist' [Icon and iconicity], L'viv, 2001, 288 p [In Ukrainian]. 
11. Pavlychko D. Tvory : v 3 t. [Works: in 3 volumes] Kyiv, 1989, Vol.1., Poeziyi, 501 p [In Ukrainian].

12. Pluzhnyk Ye. Poeziyi [Poems], Kyiv, 1988, 415 p [In Ukrainian].

13. Svyati pochuttya, zakladeni v molytvu : antolohiya ukrayins'koyi literaturnoyi molytvy [Holy feelings embedded in prayer: anthology of Ukrainian literary prayer], Bukharest, 2004, 399 p [In Ukrainian].

14. Taranovskiy $K$. Formy obshcheslavyanskogo i tserkovnoslavyanskogo stikha v drevnerusskoy luterature XI-XIII vv. [Forms of Slavonic and Church Slavonic verse in Old Russian literature of XI-XIII centuries], O poezii i poetike [About poetry and poetics], Moskva, 2000, pp. 257-273 [In Russian].

15. Ukrayins'ka poeziya : Kinets' XVI - pochatok XVII st. [Ukrainian poetry of the end of XVI - earlier XVII century], Kyiv, 1978, 430 p [In Ukrainian].

16. Khvyl'ovyy M. Tvory : v 2 t. [Works: in 2 volumes], Kyiv, 1990, Vol.1, Poeziya. Opovidannya. Novely. Povisti, 650 p [In Ukrainian].

17. Khrestomatiya ukrayins'koyi relihiynoyi literatury: u 2 t. [Anthology of Ukrainian religious literature: in 2 volumes], Vol. 2, Issue 1, Munchen, London, 1988, 552 p [In Ukrainian].

\section{АННОТАЦИЯ \\ Ирина Даниленко. Молитва Господня в художественной рецепции украинских поэтов}

Статья посвящена анализу процесса творческого восприятия украинскими поэтами разных периодов развития национальной литературы текста наиболее авторитетной христианской молитвы - Молитви Господней («Отче наш»). Исходя из убеждения, что молитва является зеркалом духовной зрелости человека, исследовательница объясняет взаимодействие этических доминант христианской доктрины с авторской аксиологией, a также с ведущими этическими, философскими и эстетическими тенденциями эпохи.

Ключевые слова: украинские поэты, Молитва Господня («Отче наш»), молитва каноническая/ поэтическая, сакральный оригинал, поэтическая инновация.

\section{ABSTRACT \\ Iryna Danylenko. The Lord's Prayer in art the reception of Ukrainian poets}

The article is devoted to analysis of the process of creative perception of the Ukrainian poets of the different periods of development of the national literature the text of the most authoritative of the Christian sacred text - the Lord's Prayer. Based on the conviction that prayer is a mirror of spiritual maturity of the person, the researcher explains the interaction of ethical dominants of Christian doctrine with the author's axiology, as well as with the leading ethical, philosophical and aesthetic trends of the era. Comparative analysis of Ukrainian innovation of Lord's Prayer gives the suggests that old Ukrainian poets sought to recreate and aesthetize all moral and spiritual dominants of the Lord's Prayer, obviously, with educational purposes. It was observed that remakes, imitations and stylizations of "paternoster" in newest time reflect the poets' desire to understand their values, historical, social, political, ideological problems through deeply emotional rethinking of the basic concepts of Christian exemplarity and its reference to God. The most popular version of "paternoster" among Ukrainian poets of the nineteenth and twentieth centuries - a rethinking of the sacred text in a spirit of prayer for Ukraine, where cross-cutting becomes the motive of suffering Ukrainian people in need of God's mercy and salvation, and where the kingdom of heaven is society of peace and harmony.

Key words: Ukrainian poets, the Lord's Prayer («Our Father»), canonical prayer / poetic prayer, sacred original, poetic innovation. 